This item was submitted to Loughborough's Research Repository by the author.

Items in Figshare are protected by copyright, with all rights reserved, unless otherwise indicated.

\title{
Water demand management: shifting urban water management towards sustainability
}

\author{
PLEASE CITE THE PUBLISHED VERSION \\ PUBLISHER \\ (C) IWA Publishing
}

VERSION

AM (Accepted Manuscript)

LICENCE

CC BY-NC-ND 4.0

\section{REPOSITORY RECORD}

Kayaga, Sam, lan K. Smout, and Hana Al-Maskati. 2019. "Water Demand Management: Shifting Urban Water Management Towards Sustainability". figshare. https://hdl.handle.net/2134/6085. 
This item was submitted to Loughborough's Institutional Repository (https://dspace.lboro.ac.uk/) by the author and is made available under the following Creative Commons Licence conditions.

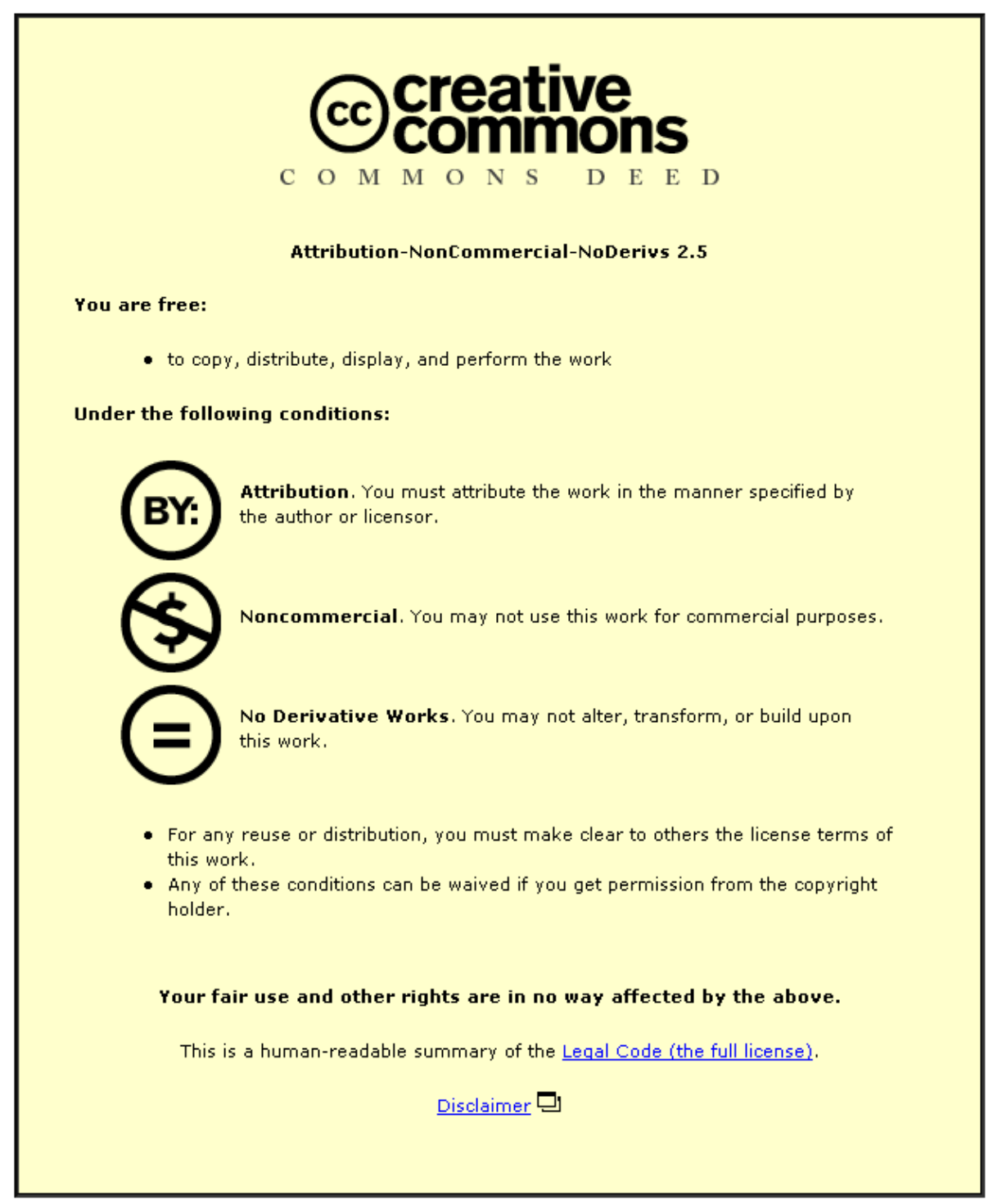

For the full text of this licence, please go to: http://creativecommons.org/licenses/by-nc-nd/2.5/ 


\title{
WATER DEMAND MANAGEMENT - SHIFTING URBAN WATER MANAGEMENT TOWARDS SUSTAINABILITY
}

\author{
By Sam Kayaga ${ }^{1}$, Ian Smout and Hana Al-Maskati
}

Water, Engineering and Development Centre (WEDC), Department of Civil and Building Engineering, Loughborough University, LEICESTERSHIRE, LE113TU, UK.

Key Words: Sustainability, Urban Water Management, Water Demand Management.

\begin{abstract}
Whereas the world population is increasing at a high rate, especially in urban areas, the water resources have not only remained constant, but they are being polluted at a high rate, which inevitably results in fresh water scarcity. Current urban water management concepts and practices cannot adequately respond to these changes. There is need for water professionals to change the way they manage water resources in urban areas if we are to ensure economic and environmental sustainability. In addition to consideration of supplyside options, we need to apply water demand management (WDM) tools both on the utility and end-user sides. This paper describes the basic concepts of WDM, provides a case study of their application in Bahrain, and briefly introduces the five-year EU-funded SWITCH Project that aims at creating a paradigm shift in urban water management practices.
\end{abstract}

\section{Introduction}

The world population is increasing rapidly. The current population is estimated at 6.5 billion, having increased by a factor of four in the past century. It is projected to grow to over 8 billion by 2025 (IPCC, 2000). Water resources are essential for the existence of the human population and other members of the biodiversity. Yet the water resources have not only remained constant but have increasingly been polluted by the growing population. The rate of abstraction of freshwater has grown rapidly in tandem with human population growth. For example human water use increased by a factor of six in the past century (Andresen, Lorch \& Rosegrant, 1997). It is estimated that global water withdrawals will increase by 35\% between 1995 and 2020 (ibid). To cope with a continuously increasing population, per capita water availability is steadily declining.

While global freshwater supplies are adequate to meet global demand for the foreseeable future, the world's freshwater is poorly distributed across countries, within countries and between seasons. Hence, practical distribution problems concerned with time, space and affordability lead to a widening gap between demand and supply in many parts of the world. The water scarcity situation is compounded by the major impacts of climate change on the water resources, namely shorter duration of the precipitation seasons and increase in hydrological extremes (Stern, 2007). The shorter precipitation season, coupled with an overall larger annual precipitation leads to larger runoff volumes generated over shorter time intervals, which in turn creates complications in designing for storage and routing of floods.

Furthermore, the opportunity time for groundwater recharge is reduced, which undermines the efficiency of conjunctive utilization of surface water and groundwater. If these climate changes continue at current rates, there is predicted to be a serious reduction in dry-season water availability in many regions of the world within the next few decades. For instance, a temperature raise of $2^{\circ} \mathrm{C}$ may result in 1-4 billion people of developing countries

\footnotetext{
${ }^{1}$ Corresponding Author. Tel +44-1509-228743; Fax +44-1509-211079; Email: s.m.kayaga@Lboro.ac.uk
} 
experiencing water shortages (Stern, 2007). The water scarcity situation will get worse in the world's urban areas where it has been projected that over $50 \%$ of the world's population live since early 2007 (UN-HABITAT, 2006). It is further estimated that 95\% of the world's urban growth in the next two decades will occur in the cities of developing countries (ibid).

Parallel with the growth in population, the demand for drinking water has been increasing rapidly in urban areas of developing countries in line with rising standards of living. Yet the number of viable water resources in any country is limited and has to serve competing requirements such as domestic, industrial, irrigation, fishing, navigation, tourism, recreational, ecological and waste disposal/assimilation. Given these changes in the macro environment, water professionals face enormous challenges of ensuring that available water resources are optimally used. One way of alleviating these problems is application of Water Demand Management (WDM) concepts. The next section of this paper highlights key limitations of the conventional urban water management. Thereafter, the paper briefly describes WDM, and how its concepts have been applied to improve the urban water management situation in the Kingdom of Bahrain. Finally, the paper introduces the scope of research, development and training activities on WDM under the EU-funded SWITCH project.

\section{Limitations of the Conventional Urban Water Management Concept}

Most of the points highlighted in this section have been drawn from the SWITCH Project Annex on Description of Works (SWITCH, 2006). The current conventional urban water management concept, which was developed in the $19^{\text {th }}$ century mainly to counter epidemics caused by water-born pathogens, cannot adequately respond to the changes enumerated above. Under this conventional system, the design for the urban water infrastructure services was mainly driven by public health considerations, rather than environmental sustainability. Understandably, this did not take due consideration of the rapid population growth rates, high levels of urbanisation, industrial growth and climate change which the world is currently experiencing. One of the key limitations of the conventional urban water management concept is over-emphasis on managing supply at the expense of considering demand options. The traditional response to the ever increasing water demand is development of new water sources. Such supply management tendencies are neither environmentally sustainable nor economically viable, as they lead to higher rates of depletion of the finite water resources at higher marginal costs.

Another key limitation is the use of high quality drinking water for all domestic purposes. Yet, there are substantial differences in water quality demanded for different uses in the household. Only drinking and cooking, which consume a small proportion of the total household demand, require high quality treated water. Other uses may be satisfied with poorer quality water, which could permit re-use of water from one application to another. Use of such high quality water for all household chores has implications on the production costs and the unnecessarily higher pollution loads arising out of the treatment processes. Furthermore, large volumes of drinking water are used to transport excreta over long distances to centralised wastewater treatment plants. Limitations of such a sewerage system are: (i) the centralised end-of-pipe treatment processes to absorb large volumes of wastes and effluents are being stretched to their limits, (ii) valuable resources in terms of water and nutrients are wasted during the transportation; (iii) extensive sewer networks are costly and difficult to construct and maintain; and (iv) the performance of large-scale treatment facilities is reduced under wet weather conditions, when wastewater is heavily diluted. 
Furthermore, the institutional setup of the conventional urban water management systems engender a highly fragmented division of responsibilities and tasks. In many cases, different organisations do not share information, and activities in the catchments are not coordinated. As a result, many managers of urban water utilities do not fully appreciate the impact their operations have on the environment, and environmental sustainability is rarely part of the corporate objectives. Where there are efforts to mitigate against environmental degradation, the efforts are mostly ad-hoc, and often fragmented.

It is clear from the above consideration that application of the conventional urban water management concept to contemporary times will not ensure sustainability. The current environmental management issues call for a change in the way urban water resources are managed. Today's water sector professionals are faced with enormous challenges of effectively managing the ever dwindling water resources to deliver water and sanitation services while minimising the negative impacts on the environment. The 2002 World Summit on Sustainable Development (WSSD) recognised the need to adopt Integrated Water Resources Management (IWRM) for promotion of more sustainable approaches to water development and management. IWRM is an approach that ' ...promotes the coordinated development and management of water, land and related resources, in order to maximize the resultant economic and social welfare in an equitable manner without compromising the sustainability of vital ecosystems' (Global Water Partnership, 2000, p.22). However, there is inadequate literature on how IWRM concepts could be best be applied to urban water management (Global Water Partnership, 2006). WDM is one of the principle tools that enhances IWRM approaches in urban water and sanitation services.

\section{Water Demand Management: concepts, tools and benefits}

Water demand management (WDM) may be defined as the development and implementation of strategies, policies, measures or other initiatives aimed at influencing demand, so as to achieve efficient and sustainable use of the scarce water resource (Savenije and van der Zaag, 2002). Demand management is any action that modifies the level and/or timing of demand for a particular resource (White and Fane, 2001).

WDM is a key aspect of the Integrated Resource Planning (IRP) approach that was first applied in the energy sector in the 1980s, and was adopted to correct a historical tendency of over-emphasis on supply options for responding to the ever-increasing demand for finite resources such as energy and water. IRP may be defined as a comprehensive form of planning that uses an open and participatory decision-making process to evaluate least-cost analyses of demand-side and supply side options (Beecher, 1995).

IRP is a process in which water utilities determine the least cost options that they can use to provide their customers with water-related services that they demand rather than the water itself (Howe and White, 1999). The guiding philosophy for IRP is that demand for a resource such as water is not a demand for that resource itself but rather for the services that the resource provides, often called end uses. As such, consumers are perceived to generate demand for the end uses, such as clothes washing or toilet flushing, rather than a demand for litres of water (White and Fane, 2001). Therefore, one way to fulfil the demand could be increasing the efficiency of resource use, as it is assumed that providing the same services with less resources makes no difference to the consumer.

The IRP process identifies the most efficient means of achieving the goals, while considering the costs of the project impacts on other societal objectives and environmental management goals (White and Fane, 2001). One of the key steps involved is the end use 
analysis, which investigates in what ways consumers use the water, to as great a detail as possible. Other key stages of IRP include developing and analysing demand management options, working out the costs and benefits of these measures, and comparing them with available supply options (ibid). There are four major categories of WDM measures (White and Fane, 2001): those measures that (i) increase system efficiency at the utility level; (ii) physically increase end use efficiency; (iii) promote locally available resources not currently being used, such as rainwater harvesting; (iv) promote substitution of resource use, e.g. use of waterless sanitation; and (v) use economic instruments to bring about an improvement in resource usage, such as use of tariffs. Table 1 shows commonly applied WDM tools.

Table 1. WDM measures commonly applied (adapted from Jalil and Njiru, 2006)

\begin{tabular}{|c|c|}
\hline $\begin{array}{c}\text { Level of } \\
\text { intervention }\end{array}$ & Measures \\
\hline \multirow{3}{*}{ Policy } & Creation of an enabling environment for utilities to adopt WDM \\
\hline & Approval of tariffs that promote WDM \\
\hline & Approval of plumbing bye-laws that encourage WDM \\
\hline \multirow{12}{*}{$\begin{array}{l}\text { Service } \\
\text { Provider }\end{array}$} & Reduction in system losses, including leak detection and repair \\
\hline & Pressure reduction, reduced mains flushing or reservoir cleaning \\
\hline & Metering, pricing and billing reforms \\
\hline & Control of illegal use of water \\
\hline & Control of overflows from tanks \\
\hline & Ensuring all-time accuracy of meters \\
\hline & Raising awareness of importance of WDM among staff \\
\hline & Ensuring accurate billing \\
\hline & Providing information to customers on economic water use \\
\hline & Education, training, and advisory services to customers on WDM tools \\
\hline & Performance standards for efficiency of equipment and appliances \\
\hline & Incentives for purchase and installation of efficient water using equipment \\
\hline \multirow{10}{*}{ Consumer } & Using water-efficient processes in industries \\
\hline & Adapting clean technology in the manufacturing processes of industries \\
\hline & $\begin{array}{l}\text { Installing low water use appliances (e.g. low flush/double flush cisterns for } \\
\text { toilets, water efficient washing machines, low-flow shower roses/faucets) }\end{array}$ \\
\hline & Awareness for conservation of water \\
\hline & In-house/industrial recycling of wastewater \\
\hline & Prevention of overflowing tanks \\
\hline & Timely repair of leaks on the service pipeline \\
\hline & Timely repair or replacement of faulty faucets and plumbing fixtures \\
\hline & Practicing water-efficient gardening \\
\hline & Use of alternative water sources (e.g. storm-water) for some applications \\
\hline
\end{tabular}

Application of WDM measures in several countries has yielded positive results. Achievements in terms of water savings have been reported by different organisations in the literature, a few examples of which are summarised in Table 2. Information in Table 2 shows significant savings in water use arising from a variety of interventions. If these interventions are scaled up qualitatively and quantitatively across the whole water service area, they could result in significant reductions of pumping energy costs and in amounts of water treatment chemicals. Furthermore, reduced peak demands will result in delayed timing of capital infrastructure expansions. 
Table 2. Examples of benefits of WDM tools reported in the literature

\begin{tabular}{llll}
\hline \multicolumn{1}{c}{ Reference } & Study setting & \multicolumn{1}{c}{ Action } & \multicolumn{1}{c}{ Achievement } \\
\hline $\begin{array}{l}\text { Smith et al }, \\
2001\end{array}$ & $\begin{array}{l}\text { Millennium } \\
\text { Dome London }\end{array}$ & $\begin{array}{l}\text { Use of a combination of poor } \\
\text { ground water, grey water and } \\
\text { rainwater for toilet flushing }\end{array}$ & $\begin{array}{l}\text { Savings of about } 50 \% \text { of } \\
\text { potable water consumption }\end{array}$ \\
\hline $\begin{array}{l}\text { Ahn \& Song, } \\
2000\end{array}$ & $\begin{array}{l}\text { Lotte World, } \\
\text { Seoul, S.Korea }\end{array}$ & $\begin{array}{l}\text { Reclamation of wastewater for } \\
\text { toilet flushing }\end{array}$ & $\begin{array}{l}18 \% \text { (900m3/day) of total } \\
\text { water supply provided }\end{array}$ \\
\hline $\begin{array}{l}\text { Yeoh et al, } \\
2001\end{array}$ & Malaysia & $\begin{array}{l}\text { Reusing the spent wash in } \\
\text { molasses dilution and } \\
\text { fermentation }\end{array}$ & $\begin{array}{l}40 \% \text { reduction in freshwater } \\
\text { consumption }\end{array}$ \\
\hline $\begin{array}{l}\text { March et al, } \\
2004\end{array}$ & Mallorca & $\begin{array}{l}\text { Recycling of grey water to flush } \\
\text { toilets at a local hotel }\end{array}$ & $\begin{array}{l}\text { 23\% of water consumption } \\
\text { was saved }\end{array}$ \\
\hline
\end{tabular}

\section{WDM activities in Bahrain Kingdom}

The Kingdom of Bahrain is a small island located in the Arabian Gulf, East of Saudi Arabia. Bahrain has a surface area of 665 square kilometres, with no inland water body. With an urbanisation rate of $92 \%$, the total population was estimated at about 650,000 in 2001, of which about one-third are non-nationals, and with an estimated annual growth rate of 2.7\% (Government of Bahrain, 2002). Bahrain adopted a market-based economy, whose real Gross Domestic Product (GDP) was estimated at 7.2 billion US dollars in 2001 (i.e. per capita GDP of US\$11, 067), having an annual growth rate of 4.4\% for the period 19972001 (ibid). Petroleum production and refining in the past dominated Bahrain's economy, contributing $18 \%$ of the real GDP in 2000 . However, the Government is currently in the process of reducing the dependence on oil, by enhancing non-oil revenues and increasing the role of the private sector (ibid).

Bahrain is a water-scarce country. Characterised by a harsh desert climate, with no river or lake, Bahrain receives an average annual precipitation of less than $80 \mathrm{~mm}$. Historically, Bahrain has relied on groundwater for both agriculture and municipal requirements. In the first half of the $20^{\text {th }}$ century, much of the water requirements were satisfied from tapping springs and hand-dug wells. However, as exploration of offshore reservoirs of crude oil and gas progressed, leading to increased water demand, pumped boreholes became the normal method of extracting groundwater. By mid-1980s, demand far outstripped supply, to the extent that the groundwater resources were overexploited by $125 \%$, leading to a significant drop in groundwater level, the deterioration of groundwater quality, drying up of springs, salinisation and deterioration of agricultural lands (Government of Bahrain, 2002). It was estimated that by 1995, Bahrain was overexploiting groundwater resources by about 100 million m3 per annum (FAO, 1997). In response to this situation, the Government of Bahrain invested in increasing the desalinated water production capacity, which reached a production level of 131,000 $\mathrm{m}^{3}$ /day by 1987 (accounting for about $48 \%$ of the total water production), and raising to 205,000 $\mathrm{m}^{3} /$ day in 1995 (Murakami, 1995). In 2005, desalination plants contributed 69\% of water requirements in Bahrain (Government of Bahrain, 2005). Apart from the high costs of water desalination, which ranges between US\$1-1.5 per $\mathrm{m}^{3}$ in the Arabian Peninsula, desalination plants pollute the environment by emitting oxides and marine pollutants from the rejected brine (UNEP, 1999).

Notwithstanding the environmental and economic problems arising out of the water scarcity problems in Bahrain, demand for domestic water supply has been increasing at an average of $6 \%$ per annum since 1986, estimated to be above 500 litres per capita per day in 2000 (Government of Bahrain, 2002). To respond to such an unsustainable situation, the 
Government of Bahrain instituted a programme in 1986 to apply WDM measures at the utility and consumer levels. The Ministry of Electricity and Water was restructured to adequately carry out WDM tasks. Figure 1 shows the relevant departments responsible for WDM tasks. The main tasks are distributed as follows:

o Maintenance and Engineering Department is responsible for active leakage control, timely repair of pipe network, and accuracy of meters (physical loss management);

o Customer services Department is responsible for customer water meter reading and generating monthly bills (apparent loss management); and

o Water Conservation Department is responsible for carrying out research and development in water conservation, investing high consumptions and locating leaks on consumers' premises, installing water saving devices, and carrying out public education and sensitisation (end-use management).

Figure 1. Departments of Bahrain Ministry of Electricity \& Water responsible for WDM

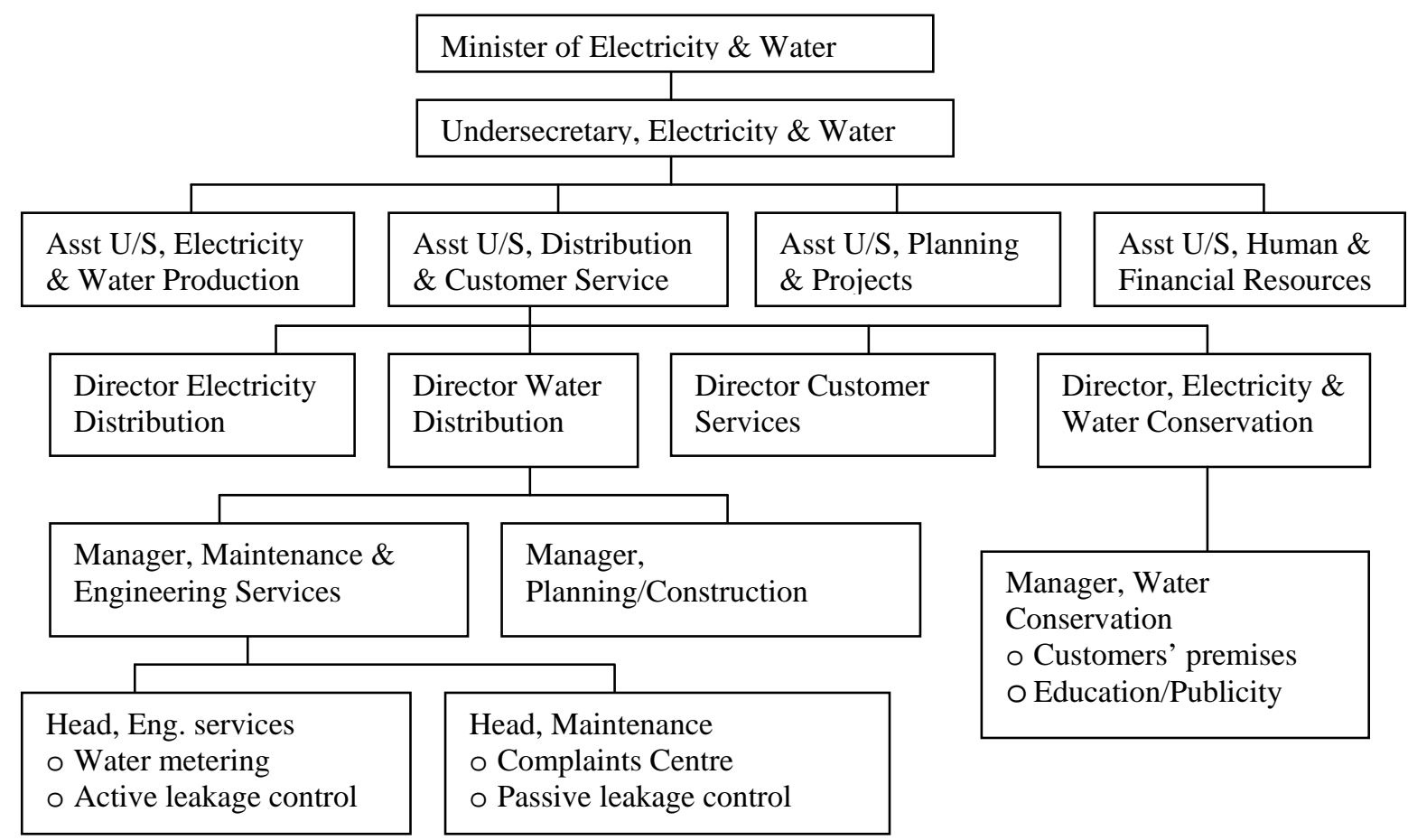

In 1986, at the beginning of the WDM programme, non-revenue water (NRW) was estimated at 35\% of total water production (Government of Bahrain, 2002). In response, the Ministry of Electricity and Water set up a dedicated Waste Detection Unit (WDU), which was charged with the task of ensuring the reduction of NRW to acceptable levels, through active leak detection. Headed by a senior engineer, the WDU is composed of a validation engineer, a field engineer, senior technicians, data entry technicians, foremen, pipe fitters, inspectors and trade workers. The Unit is well facilitated with advanced leak detection equipment (e.g. listening devices, noise loggers, pipe locators and leak noise correlators) and 10 vehicles. Functional waste zones have subsequently been established in 95\% of the water distribution network. Together with similar measures such as pressure management, NRW has been subsequently been reduced to the current $25 \%$ ratio. Further reduction in water losses could be achieved by putting more emphasis on minimising water theft and illegal consumption, and improving the accuracy of meters.

The Water Conservation Department has been promoting the use of water-efficient methods at the end users' side. However, not as much progress has been achieved to 
influence consumers to use water more efficiently, as may be observed from the raising average per capita consumption. One key shortcoming of the water conservation program in Bahrain is the fragmented and non-integrated methodologies being utilised: an integrated resource planning process should be adopted, to evaluate least cost analyses of demand-and supply side-options on a longer-term basis, and in a more systematic manner. Secondly, the tariff in Bahrain, which is highly subsidized for households with consumptions of up to $60 \mathrm{~m}^{3}$, does not encourage consumers to use water economically. There is need, therefore, to revise the water tariff so that it promotes water conservation.

\section{WDM under the SWITCH Project}

WDM is one of the themes being studied by the SWITCH research project, an EU-funded five-year integrated project that started in 2006. SWITCH is an acronym for 'Sustainable Water management Improves Tomorrow's Cities' Health'. The overall goal of SWITCH is to trigger a paradigm shift in current urban water management practices by developing, applying and demonstrating a range of tested scientific, technological and socio-economic solutions and approaches that contribute to the achievement of sustainable and effective urban water management schemes in the 'city of tomorrow (i.e. projected 30-50 years from now)'. The SWITCH project aims at developing efficient and interactive urban water systems and services in the city's geographical and ecological setting, which are robust, flexible and responsive to a range of global change pressures. The Water, Engineering and Development Centre (WEDC) of Loughborough University is one of the 32 research consortium partner institutions for the SWITCH Project, which is contributing to the project theme on 'efficient water supply and water use for all'. WEDC is leading on Work Package 3.1, which deals with WDM.

Working with other themes in an integrative manner, Work Package 3.1 of the SWITCH Project is to develop and test holistic WDM tools, encompassing commercial and physical aspects, in order to reduce water wastage and provide educational materials on the two main components for the benefit of service providers. In the past year, a literature review has been conducted to assess the current developments in the field of WDM. This review has formed a basis for planning the fieldwork in City of Zaragoza, Spain, one of the SWITCH demonstration cities. WEDC will work in partnership with the relevant IWA Task Forces to carry the fieldwork, which will mainly involve (i) demonstration of IWA recommended best practices in water loss management; (ii) adaptation of the IWA international demand management framework to current conservation measures; (iii) developing the current Zaragoza economic tariff into an international case study; and (iv) commissioning innovative research in advanced methods of remote and non-intrusive methods of leak detection, consumption measurement, pressure zoning, and how asset management could automatically be linked with WDM. Case studies on WDM will also be carried out in other cities. Findings from the fieldwork will be developed into training materials, and WDM courses will subsequently be delivered to various audiences in the course of the project period.

\section{Conclusion}

The looming water scarcity coupled with serious negative environmental impacts currently being experienced compels water professionals in urban areas to rethink the way they manage the water resources. In addition to supply-side options, urban water managers need to apply WDM tools in the utility distribution systems and at the end-use level, in order to ensure sustainable provision of water services. The case of Bahrain has shown that in order to create a considerable impact, these tools need to be applied in a holistic manner, within the framework of Integrated Resource Planning. Through collaboration with the relevant 
IWA Task Forces, planned research activities under the EU-funded SWITCH project will contribute to greater applicability of WDM tools in different geographical and institutional locations. Through its research, development, demonstration and training activities, the SWITCH project will contribute to making urban water management more economically and environmentally sustainable.

\section{References}

Ahn, K.H. and Song, K.G. 2000. Application of micro-filtration with a novel fouling control method for reuse of wastewater from a large-scale resort complex, Desalination, 129 pp. 207-216.

Andresen, P.P., Lorch, R.P. and Rosegrant, M.W. 1997. The World Food Situation: Recent Development, Emerging Issues, and Long-term Prospects, Food Policy Report, International Food Policy Research Institute, Washington D.C.

Beecher, J.A. 1995. Integrated resource planning fundamentals, Journal AWWA, 87(6) 3448.

FAO. 1997. Irrigation in the Near East in Figures. Water Report No. 9, FAO.

Global Water Partnerships. 2000. Integrated Water Resources Management, TAC

Background Papers No.4, Stockholm, Sweden.

Global Water Partnerships. 2006. Urban Water and Sanitation Services; An IWRM

Approach, TAC Background Papers No.11, Stockholm, Sweden.

Government of Bahrain. 2002. State of Bahrain Report to Earth Summit, World Summit on Sustainable Development, Johannesburg.

Government of Bahrain. 2005. Ministry of Electricity and Water Annual Water Production - 2005, Water Transmission Directorate Unpublished Report.

Howe, C. and White, S. 1999. Integrated resource planning for water and wastewater Sydney case studies, Water International , 24(4) 356-362.

IPCC. 2000. Emissions Scenarios, A special report of Working Group II of the Intergovernmental Panel on Climate Change. Cambridge University Press, Cambridge. Jalil, A. and Njiru, C. 1996. Water Demand Management in Urban Water Supplies Present and Future Challenges, Unpublished Report, Loughborough University. March, J.G., Gual M. and Orozco, F. 2004. Experiences on grey water re-use for toilet flushing in a hotel (Mallorca Island, Spain), Desalination, 164, pp. 241-247.

Murakami, M. 1995. Managing Water for Peace in the Middle East: Alternative Strategies, The United Nations University Press.

Savenije, H. and van der Zaag, P. 2002. Water as an economic good and demand management: paradigms with pitfalls,. Water International, 27 (1), 98-104.

Smith, A.J., Khow, J., Lodge, B. and Bavister, G. 2001. Desalination of poor quality brackish groundwater for non-potable use, Desalination, 139 , pp. 207-215.

Stern, N. 2007. The Economics of Climate Change: The Stern Review, Cambridge University Press.

SWITCH, 2006. SWITCH Description of Works, at http://www.switchurbanwater.eu/ UNEP.1999. Global Environmental Outlook - 2000 Report. UNEP.

UN-HABITAT. 2006. State of the world's cities, 2006/7, UN-HABITAT.

White, S.B. and Fane, S.A. 2001. Designing Cost Effective Water Demand Management Programs in Australia, Water Science and Technology, Vol. 46, No 6-7, pp.225-232. Yeoh, B.G, Chen, S.S, Aziz, A.A, Nee, T.Y., Chong, T.C., Graaff, V.D. 2001. Cleaner production in the distillery industry - the Malaysia experience, in Proceedings of the Third Asia Pacific Roundtable Conference for Cleaner Production, Manila, Philippines.

http://www.aprcp.org/articles/papers/yeoh.htm. 